\title{
The Contextual Effect of Village on Early Marriage in Wonogiri, Central Java
}

\author{
Mirna Prawita'), RB Soemanto²), Bhisma Murti) \\ 1)Masters Program in Public Health, Universitas Sebelas Maret \\ 2)Faculty of Social and Political Sciences, Universitas Sebelas Maret
}

\begin{abstract}
Background: In spite of international agreements and national laws, marriage of girls $<18$ years of age is common worldwide and affects millions. Child marriage is a human rights violation as it prevents girls from obtaining an education, enjoying optimal health, bonding with others their own age, maturing, and ultimately choosing their own life partners. Child marriage is driven by poverty. Therefore, village level of prosperity may have a contextual effect on child marriage. The purpose of this study was to examine the contextual effect of village on early marriage in Wonogiri, Central Java.

Subjects and Method: A case control study was conducted at 25 villages in Wonogiri, East Java, in December 2018. A sample of 225 women was selected by fixed disease sampling. The dependent variable was early marriage. The independent variables were intention, attitude, perceived behavior control, paternal education, maternal education, and information exposure. The data were collected by questionnaire and analyzed by a multilevel analysis.

Results: The risk of early marriage increased with exposure to negative information $(b=0.97$; $95 \% \mathrm{CI}=0.20$ to $1.72 ; \mathrm{p}<0.012)$, negative attitude $(\mathrm{b}=1.67 ; 95 \% \mathrm{CI}=1.00$ to $2.67 ; \mathrm{p}<0.001)$, and strong intention $(\mathrm{b}=1.86 ; 95 \% \mathrm{CI}=1.03$ to $2.70 ; \mathrm{p}<0.001)$. The risk of early marriage decreased with high paternal education $(\mathrm{b}=-0.81 ; 95 \% \mathrm{CI}=-1.57$ to $-2.14 ; \mathrm{p}=0.009)$, high maternal education $(b=-0.65 ; 95 \% \mathrm{CI}=-1.37$ to $0.85 ; \mathrm{p}=0.083)$, strong perceived behavior control $(\mathrm{b}=-1.77 ; 95 \% \mathrm{CI}=-$ 1.77 to $-0.20 ; \mathrm{p}=0.013)$. Village had contextual effect on early marriage with $\mathrm{ICC}=15 \%$.

Conclusion: The risk of early marriage increases with high exposure to information, negative attitude, and strong intention. The risk of early marriage increases with high paternal education high maternal education, strong perceived behavior control. Village has contextual effect on early marriage.
\end{abstract}

Keywords: intention, early marriage, parental education, information exposure

\section{Correspondence:}

Mirna Prawita. Masters Program in Public Health, Universitas Sebelas Maret, Jl. Ir. Sutami 36 A, Surakarta 57126, Central Java, Indonesia. Email: mirna.prawita2013@gmail.com. Mobile: 085642331691.

\section{BACKGROUND}

Marriage that meets the criteria for healthy age is strongly related to women's reproductive health, namely at the age of 20-35 years (Wahyuningsih, 2009). However, in a number of countries, especially developing countries, there are many marriages in adolescents with a variety of backgrounds, which have become the focus of the international community (Thantowy, 2016). Early marriage is a marriage that is carried out when a person is under 18 years old (Le et al., 2014).

More than 700 million women worldwide, married before the age of 18. Meanwhile, one in three women (around 250 million women) get married before the age of 15 (UNICEF, 2016). Based on data from the United Nations Development Economic and Social Affairs (UNDESA) in 2011, Indonesia is the 37th country with the highest number of early age marriages in the world 
and the second highest premature marriage in the Association of Southeast Asian Nations (ASEAN) after Cambodia. Based on the 2013 Basic Health Research (Riskesdes) conducted by the Ministry of Health of the Republic of Indonesia (RI Ministry of Health), 26\% of women aged 15-19 years had already married. This means that marriage is done when the reproductive organs have not developed optimally. In Indonesia there are \pm 1 , ooo girls (16-17 years) married every day (UNICEF, 2016).

The survey conducted by the Indonesian Women's Coalition (KPI) during 2016, in Central Java, 30,128 underage women filed for dispensation in order to get married. From these data, 2,900 children were approved and \pm 28 , ooo children were married with age or under the law. Based on data from the Ministry of Religion of Wonogiri, in Wonogiri Regency premature marriage in January-July 2018 is 26 cases. Meanwhile, data from the Wonogiri Regency Religious Court, marriage dispensation in underage adolescents in 2016 were 63 cases. In 2017, there are 48 cases, and in 2018, until September, there are 44 cases. Most marriage dispensations are given because young women are already pregnant. Therefore, many early age couples drop out of school.

Indonesia has a law that regulates marriage. Marriage is regulated by the Law of the Republic of Indonesia Number 1 Year 1974. In Law Number 1 Year 1974 Article 7, marriage is only permitted if the male reaches the age of 19 years and the woman has reached the age of 16 years. However, this law is against the age of ideal marriage according to the BKKBN, that biological and psychological maturity for marriage is ideal, namely at the age of 20-25 years for women and 25-30 years for men.

Early marriage causes several negative effects such as bleeding in early preg- nancy which causes death. Based on data from the 2012 Indonesian Demographic and Health Survey (IDHS), the Maternal Mortality Rate (MMR) in Indonesia amounts to 359 per 100,00o live births. In addition, early marriage has the potential to cause reproductive damage and chronic complications such as obstetric fistula because the pelvis is not ready for the process of pregnancy and childbirth (Jannah, 2012; Fadlyana et al., 2009). Early pregnancy also affects the baby they are carrying because of the risk of premature occurrence, malnutrition, diarrhea, low birth weight, even death before the age of 5 years (UNICEF, 2016; Raj et al., 2010).

The negative effects of other early marriages include teenagers dropping out of school and increasing divorce rates. Based on research conducted by Sakine (2017), proving that marriage in adolescents significantly increases the risk of girls dropping out of school, especially in developing countries. In addition, in South Africa a study conducted by Rosenberg (2015) found that teens were at high risk of dropping out of school when they were pregnant. Early marriage raises psychological problems such as anxiety, mentally unprepared and less able to control his own life (decision making and problem solving). Therefore, there are often disputes between married couples which lead to divorce. Based on data from the Wonogiri District Religious Court, until September 2018, divorce in Wonogiri District showed a high number of 1,239 divorce cases (Gage, 2013; UNICEF, 2016; Raj et al., 2010; Jannah, 2012; Fadlyana et al., 2009).

There are several studies that explain the determinants of early marriage such as parental education and exposure to information media (Landung et al., 2009; Fauziah et al., 2015; Harahap et al., 2014; Jannah, 2012; Soetjiningsih, 2010; Isro- 
kiyah, 2017) . In addition, important factors are also identified as contextual factors for early marriage. This study factors related to the intention of adolescents to do early marriage are explained through Theory of Planned Behavior (TPB). Intention is determined by attitude towards certain behaviors. TPB has been used to predict various behaviors related to the health sector, including the intention to conduct early marriage (He et al., 2015; Catalano et al., 2016).

Analysis of contextual factors is needed as a follow-up effort in knowing the important factors of early marriage. It is expected that using a multilevel approach can be known the influence of various levels and levels that have a higher influence on early marriage behavior. Therefore, the author is interested in conducting a study on the determinants of early marriage in Wonogiri, East Java.

\section{SUBJECTS AND METHOD \\ 1. Study Design \\ This was an analytical observational study with a case control design. The study was conducted in 25 villages from 3 sub-dis- tricts in Wonogiri, East Java, in December 2018.}

\section{Population and Samples}

The target population of this study were women who carried out early marriages. The source population of this study was women who conducted early marriages in 3 sub-districts in Wonogiri Regency. The total sample of 225 women from 25 villages was taken using the fixed disease sampling.

\section{Study Variables}

The dependent variable is early marriage. Independent variables are parental education, exposure to media information, attitude, perceptions of behavioral control, and intentions. Data collection was carried out using questionnaires and analyzed by multilevel logistic regression.

\section{Operational Definition of Variables}

Early marriage was defined as a marriage carried out by teens who are less than 18 years old. The measurement scale was categorical, coded o for no and 1 for yes.

Parental education was defined as the level of formal education that is successfully completed by the father and mother when their daughter is married. The measurement scale was categorical, coded o for $<$ Senior high school and 1 for $\geq$ Senior high school.

Exposure to information was defined as adolescent exposure to media information from magazines, the internet, and cellphones about sexual behavior, pornography, and early marriage. The measurement scale was continuous and transformed into dichotomous, coded o for low (score $<7$ ) and 1 for high (score $\geq 7$ ).

Attitude was defined as the tendency of mothers to judge and respond in the form of beliefs and feelings towards early marriage behavior. The measurement scale was continuous and transformed into dichotomous, coded o for positive (score $>6$ ) and 1 for negative (score $\geq 6$ ).

Perceived behavior control was defined as the perception of adolescents about the advantages and disadvantages of early marriage, adolescents are able to control their ability to conduct behavior and the extent to which external factors can shape and influence it. The measurement scale was continuous and transformed into dichotomous, coded o for weak (score <7) and 1 for strong (score $\geq 7$ ).

Intention was defined as the readiness of adolescents in making conscious decisions for early marriage. The measurement scale was continuous and transformed into dichotomous, coded o for weak (score <4) and 1 for strong (score $\geq 4$ ). 


\section{Study Instrument}

The study instrument used for data collection was a questionnaire. Validity test was done with content validity and face validity. Reliability tests in this study were conducted on 20 women who married early by calculating total item correlations $(>0.20)$ and Cronbach's alpha $(\geq 0.60)$.

\section{Data Analysis}

Univariate analysis in the form of categorical/dichotomous data was described in frequency (n) and percentage (\%). Bivariate analysis in this study was carried out using the correlation-square test. Multivariate analysis was conducted using multilevel logistic regression.

\section{Research Ethics}

Research ethics include research on informed consent, anonymity, confidentiality, and ethical clearance. Ethical clearance was obtained from the Research Ethics Committee Faculty of Medicine, Universitas Sebelas Maret, Surakarta, Central Java, Indonesia with number 368/UN27.6/ KEPK/2018.

$\frac{\text { RESULTS }}{\text { 1. Univariate Analysis }}$

The majority of paternal education was high (50.7\%). As many as 50.2\% adolescents had low maternal education. As many as $53.3 \%$ adolescents had high knowledge. As many as $50.7 \%$ adolescents had low information media exposure. As many as $50.7 \%$ adolescent lived with high parental income. equal gender equality (54.2\%); social norms which did not support (55.1\%); supportive subjective norms (57.3\%); positive attitude (53.3\%), weak perceived behavioral control (57.8); and weak intention (54.2\%).
Table 1. Sample Characteristics

\begin{tabular}{lcc}
\hline \multicolumn{1}{c}{ Variable } & n & \% \\
\hline Paternal education & & \\
$\quad$ Low & 111 & 49.3 \\
High & 114 & 50.7 \\
Maternal education & & \\
$\quad$ Low & 113 & 50.2 \\
$\quad$ High & 112 & 49.8 \\
Exposure to Information & & \\
$\quad$ Low & 114 & 50.7 \\
$\quad$ High & 111 & 49.3 \\
Attitude & & \\
$\quad$ Positive & 120 & 53.3 \\
$\quad$ Negative & 105 & 46.7 \\
Perceived behavior control & & \\
$\quad$ Weak & 130 & 57.8 \\
$\quad$ Strong & 95 & 42.2 \\
Intention & & \\
$\quad$ Weak & 122 & 54.2 \\
$\quad$ Strong & 103 & 45.8 \\
\hline
\end{tabular}

\section{Bivariate Analysis}

Table 2 showed the results of bivariate analysis. Table 2 showed that early marriage decreased with high paternal education $(\mathrm{OR}=0.44 ; \mathrm{p}=0.005)$, high maternal education $(\mathrm{OR}=0.40 ; \mathrm{p}=0.001)$, and perceived behavior control $(\mathrm{OR}=0.30 ; \mathrm{p}$ $<0.001)$. Early marriage increased with negative information media exposure $(\mathrm{OR}=$ 2.10; $\mathrm{p}=0.011)$, negative attitude $(\mathrm{OR}=$ $3.78 ; \mathrm{p}<0.001)$, and strong intention $(\mathrm{OR}=$ $3.35 ; \mathrm{p}<0.001)$.

\section{Multivariate Analysis}

Table 3 showed the results of multilevel logistic regression. Table 3 showed that early marriage increased with strong intention, negative information media exposure, and negative attitude.

Exposure to media information about sex and pornography has an impact on the incidence of early marriage. Women who were exposed to a lot of information about sex and pornography would increase the occurrence of early marriage compared to women who were slightly exposed $(b=0.97$; $95 \% \mathrm{CI}=0.21$ to $1.72 ; \mathrm{p}=0.012$ ). 
Table 2. The Result of Bivariate Analysis on the Factors Affecting Early Marriage

\begin{tabular}{|c|c|c|c|c|c|c|c|}
\hline \multirow{3}{*}{ Variables } & \multicolumn{4}{|c|}{ Early Marriage } & \multirow{3}{*}{ OR } & \multirow{3}{*}{ CI 95\% } & \multirow{3}{*}{$\mathbf{p}$} \\
\hline & \multicolumn{2}{|c|}{ No } & \multicolumn{2}{|c|}{ Yes } & & & \\
\hline & $\mathbf{n}$ & $\%$ & $\mathbf{n}$ & $\%$ & & & \\
\hline \multicolumn{8}{|l|}{$\overline{\text { Paternal Education }}$} \\
\hline Low & 64 & 57.7 & 47 & 42.3 & 0.44 & $0.25-0.78$ & 0.005 \\
\hline High & 86 & 75.4 & 28 & 24.6 & & & \\
\hline \multicolumn{8}{|l|}{ Maternal Education } \\
\hline Low & 64 & 56.6 & 49 & 43.4 & 0.40 & $0.22-0.70$ & 0.001 \\
\hline High & 86 & 76.8 & 26 & 23.2 & & & \\
\hline \multicolumn{8}{|l|}{ Information Media } \\
\hline \multicolumn{8}{|l|}{ Exposure } \\
\hline Low & 85 & 74.6 & 29 & $25 \cdot 4$ & 2.10 & $1.18-3.66$ & 0.011 \\
\hline High & 65 & 58.6 & 46 & 41.4 & & & \\
\hline \multicolumn{8}{|l|}{ Attitude } \\
\hline Positive & 96 & 80 & 24 & 20 & 3.78 & $2.10-6.80$ & $<0.001$ \\
\hline Negative & 54 & 51.4 & 51 & 48.6 & & & \\
\hline \multicolumn{8}{|c|}{$\begin{array}{l}\text { Perceived Behavioral } \\
\text { Control }\end{array}$} \\
\hline Weak & 73 & 56.2 & 57 & 43.8 & 0.30 & $0.16-0.56$ & $<0.001$ \\
\hline Strong & 77 & 81.1 & 18 & 18.9 & & & \\
\hline \multicolumn{8}{|l|}{ Intention } \\
\hline Weak & 96 & 78.7 & 26 & 21.3 & 3.35 & $1.87-5.90$ & $<0.001$ \\
\hline Strong & 54 & 52.4 & 49 & 47.6 & & & \\
\hline
\end{tabular}

Table 3. Multilevel Logistic Regression Analysis

\begin{tabular}{lcccc}
\hline \multicolumn{1}{c}{ Variables } & \multirow{2}{*}{ b } & \multicolumn{2}{c}{ CI (95\%) } & p \\
\cline { 3 - 4 } & & Lower limit & Upper limit & \\
\hline Paternal Education & -0.81 & -1.57 & -0.60 & 0.034 \\
Maternal Education & -0.65 & -1.38 & 0.08 & 0.083 \\
Information Media Exposure & 0.97 & 0.21 & 1.72 & 0.012 \\
Negative Attitude & 1.83 & 1.00 & 2.67 & 0.013 \\
Strong Perceived Behavioral Control & -0.99 & -1.77 & -0.21 & $<0.001$ \\
Strong Intention & 1.86 & 0.10 & 2.69 & $<0.001$ \\
N Observation = 225 & & & & \\
Loglikelihood = -104 & & & & \\
Adjusted $\mathrm{R}^{2}=0.026$ & & & & \\
ICC $=0.15$ & & & & \\
\hline
\end{tabular}

Attitude was positively associated with early marriage. A negative attitude increased the risk of early marriage compared to women with positive attitude $(\mathrm{b}=$ $1.83 ; 95 \% \mathrm{CI}=1.00$ to $2.67 ; \mathrm{p}=0.013$ ).

Paternal education was negatively associated with early marriage. High paternal education decreased the risk of early marriage among adolescents compared to low paternal education $(\mathrm{b}=-0.81 ; 95 \% \mathrm{CI}=$ -1.57 to $-0.60 ; \mathrm{p}=0.034$ ).
Maternal education was negatively associated with early marriage. High maternal education decreased the risk of early marriage among adolescents compared to low maternal education $(b=-0.65 ; 95 \% \mathrm{CI}=$ -1.38 to $0.08 ; \mathrm{p}=0.083$ ).

Perceived behavioral control was negatively associated with early marriage. Strong perceived behavioral control decreased the risk of early marriage compared to 
weak perceived behavioral control $(\mathrm{b}=$ $0.99 ; 95 \% \mathrm{CI}=-1.77$ to $-0.21 ; \mathrm{p}<0.001)$.

Intention was positively associated with early marriage. Strong intention toward early marriage increased the risk of early marriage compared to weak intention $(\mathrm{b}=1.86 ; 95 \% \mathrm{CI}=0.10$ to $2.69 ; \mathrm{p}<0.001)$.

Village had a contextual effect on early marriage in Wonogiri, East Java with $\mathrm{ICC}=15 \%$.

\section{DISCUSSION}

1. The effect of paternal education on early marriage

The result of this study showed that there was an affect of paternal education on early marriage. High paternal education decreased the risk of early marriage. The result of this study was consistent with Landung et al., (2009) which stated that parental education had an influence on the incidence of early marriage.

Asadullah (2016) stated that paternal education was influential on the incidence of early marriage. The higher paternal education lowered early marriage. It was caused by parents considered the negative effects on their daughters such as biological, psychological, and economic readiness. In addition, in some regions, most of the roles of fathers still have a higher position than mothers, including in Wonogiri District.

\section{The effect of maternal education on early marriage}

There was an affect of maternal education on early marriage. High maternal education decreased the risk of early marriage in girls compared to mothers who have low education. The result of this study was consistent with As-Syakiri et al., (2009) which stated that there was an affect of maternal education on early marriage.

Asadullah (2016) stated that maternal education also affected early marriage. The higher the maternal education, the lower the incidence of early marriage. Maternal education was influential in the parenting and assistance of children from childhood to adolescence. In addition, a study by Ahmed et al. (2013) stated that early marriage in children was also influenced by the level of education of parents (mothers) in determining the attitudes to their children.

\section{The effect of information media exposure on early marriage}

Exposure to media information about sex and pornography has an impact on the incidence of early marriage. Women who were exposed to a lot of information about sex and pornography would increase the occurrence of early marriage compared to women who were slightly exposed. The result of this study was consistent with Harahap (2014) which stated thatexposure to information media influenced early marriage behavior.

The result of this study was also in line with a study by Wijati et al., (2018) which stated thatInformation media exposure has a significant relationship to early marriage. Respondents who were exposed to information media by accessing pornography were 4 times more likely to have early marriage, compared with those who had little access to pornography accounts. This research was supported by Bugin theory which stated that the more media that display pornography, the stronger the influence of the recipients to enjoy the show, and conduct sexual behavior.

\section{The effect of negative attitude on early marriage}

Attitude had an effect on early marriage. A negative attitude would increase the incidence of early marriage.

The result of this study was consistent with Montazeri et al., (2016) which stated thata person's attitude has an influence on 
early marriage. Montazeri also mentioned that attitudes were also continuous with the intention and control of someone's behavior to conduct behaviors such as early marriage.

Attitudes toward behavior were influenced by the individual's belief in the behavior, as well as the assessment of outcome expectation of the behavior. Individuals would estimate that by doing a behavior that would give a benefit for them, then they would do it (Murti, 2018).

\section{The effect of perceived behavioral control on early marriage}

Perceived behavioral control has an effect on early marriage. A strong perceived behavioral control would reduce the incidence of early marriage compared to women with weak perceived behavioral control.

The result of this study was consistent with Babiker et al., (2016) which stated that perceived behavioral control affected early marriage. This study stated that the control factor to complete education to a higher level was one of the factors of adolescents in deciding not to get married early. In addition, the direction of parents also formed in the control of adolescents to not conduct early marriage.

Perceived behavioral control influenced simultaneously because of interactions with intentions that can influence the behavior, so that perceived behavioral control can also act as an effect modifier in the relationship between intention and behavior (Murti, 2018).

\section{The effect of intention on early marriage}

Strong intention to behavior affected early marriage. Women who have strong intention for early marriage would increase the incidence of early marriage compared to women with weak intention.

The result of this study was consistent with Babiker et al., (2016) which stated that intentions affected early marriage. In his study, someone's intention to get married early was due to various things such as: emotional, biological, and social fulfillment.

Babiker also mentioned that the intention was also influenced by the attitude and weakness of someone's control to not conduct early marriage. The strong intentions to get married early were found because people only wanted to fulfill their emotional desires. However, they did not understand the negative impacts and the consequences of having early marriage and carrying out their new roles.

\section{The contextual effect of village on early marriage}

The contextual effect of the village on early marriage in Wonogiri District has a result of $(\mathrm{ICC}=15 \%)$. It means that there was a contextual effect of village on early marriage.

It was in line with a study based on a survey from the National Family Planning Coordinating Board (BKKBN) by Fadlyana and Larasaty (2009) reported that early marriages that occurred in urban areas were lower (5.28\%) than in rural areas (11.88\%).

\section{REFERENCE}

As-Syakiri DR (2017). Hubungan antara pendidikan, peran orang tua, dan keterpaparan media massa dengan pernikahan dini di kecamatan Selo Kabupaten Boyolali. Surakarta: Universitas Muhammadiyah Surakarta.

Babiker A (2016). Knowledge, attitude and practice of early marriage in Elttondoub Area, Aljazeera State. https://www.researchgate.net/publication/ 311873830_knowledge_attitude_and _practice_of_early_marriage_in_eltt ondoub_area_aljazeera_state_2016. Diakses 02 Januari 2019 
BKKBN (2010). Pendewasaan usia perkawinan dan hak-hak reproduksi bagi remaja Indonesia. Jakarta: Badan Koordinasi Keluarga Berencana Nasional. . (2017). Usia Pernikahan Ideal 21-25 Tahun. https://www.bkkbn.go.id/ detailpost/bkkbn-usia-pernikahan-ideal-21-25-tahun. Diakses 25 Juni 2018.

Fadlyana E, Larasaty S (2009). Pernikahan usia dini dan permasalahannya. Sari Pediatri, 11(2): 136-141.

Gage AJ (2013). Child marriage prevention in Amhara Region, Ethiopia: association of communication exposure and social influence with parents/guardians' knowledge and attitudes. Social Science \& Medicine, 97: 124-133. https://doi.org/10.1016/j.socscimed.2013.08.017

Isrokiyah (2017). Hubungan kondisi sosial ekonomi orang tua dengan perkawinan usia dini remaja putri di Desa Tlogopucang dan Desa Caruban Kecamatan Kandangan Kabupaten Temanggung. Yogyakarta: Universitas Negeri Yogyakarta.

Jannah F (2012). Pernikahan dini dan implikasinya terhadap kehidupan keluarga pada masyarakat madura (perspektif hukum dan gender). Journal UIN Malang Egalita, 7(1): 12-18.

Kementerian Agama Kabupaten Wonogiri (2018). Data Pernikahan Dini Kabupaten Wonogiri. Wonogiri: Kementerian Agama Kabupaten Wonogiri.

Landung J, Thaha R, Abdullah AZ (2009). Studi kasus kebiasaan pernikahan usia dini pada masyarakat Kecamatan Sanggalangi Kabupaten Tana Toraja. Jurnal MKMI, 5(4): 89-94.

Le MTH (2013). Early marriage and intimate partner violence among adolescents and young adults in Viet Nam. J
Interpers Violence. 29(5): 889-910. doi: 10.1177/0886260513505710.

Montazeri S, Gharacheh M, Mohammadi N, Rad JA, Ardabili HE (2016). Determinants of early marriage from married girls perspectives in Iranian Setting: A Qualitative Study. Journal of Environmental and Public Health, 2016 (1): 8. http://dx.doi.org/10.1155/2016/8615929

Murti B (2018). Teori Promosi dan Perilaku Kesehatan Edisi ke 1. Surakarta: Program Studi Kesehatan Masyarakat Universitas Sebelas Maret.

Nasrullah M, Zakar R, Zakar MZ, Kramer A. (2014). Girl-child marriage and its association with morbidity and mortality of children under 5 years of age in a nationally-representative sample of Pakistan. The Journal of Pediatrics, 164(3), 639-646. https://doi.org/10.1016/j.jpeds.2013.11.017

Pemerintah Republik Indonesia (1974). Undang-Undang Republik Indonesia Nomor 1 Tahun 1974 tentang Perkawinan. Jakarta: Pemerintah Republik Indonesia.

Pengadilan Agama Kabupaten Wonogiri (2016). Data dispensasi pernikahan di Kabupaten Wonogiri. Wonogiri. (2017). Data dispensasi pernikahan di Kabupaten Wonogiri. Wonogiri. (2018). Data dispensasi pernikahan di Kabupaten Wonogiri. Wonogiri. (2018). Data Perceraian di Kabupaten Wonogiri. Wonogiri.

Raj A, Saggurti N, Winter M, Labonte A, Decker MR, Balaiah D, Silverman JG. (2010). The effect of maternal child marriage on morbidity and mortality of children under 5 in India: Cross Sectional Study of A Nationally Representative Sample. BMJ, 340. https://doi:10.1136/bmj.b4258. 
Riskesdas (2013). Riset Kesehatan Dasar 2013. Jakarta: Kementerian Kesehatan Republik Indonesia

Rosenberg M (2015). Relationship between school dropout and teen pregnancy among rural South African Young Women. https://www.ncbi.nlm.nih.gov/pmc/articles/PMC4521125/.

Sakine K, Hodgkin ME. (2017). Effect of child marriage on girls' school dropout in Nepal: Analysis of data from the Multiple Indicator Cluster Survey 2014. PLoS One, 12(7).doi:10.1371/journal.pone.0180176.

Soetjiningsih (2004). Sosiologi Pendidikan. Jakarta: EGC.
Subekti YY (2015). Pengaruh jenis kelamin, pajanan media, peran teman sebaya, pengetahuan penyakit menular seksual, kedekatan keluarga terhadap perilaku berisiko penyakit menular seksual pada anak jalanan. Surakarta: Universitas Sebelas Maret.

Thantowy D (2016). Faktor-faktor remaja memilih menikah pada usia dini. Malang: Universitas Muhammadiyah Malang.

UNFPA. (2016). Marrying Too Young. End Child Marriage. New York: United Nations Population Fund. 